\title{
A generational perspective on work values in a South African sample
}

\begin{tabular}{|c|c|}
\hline $\begin{array}{l}\text { Authors: } \\
\text { Petronella Jon } \\
\text { Freda van der } \\
\text { Ntomzodwa C }\end{array}$ & $\begin{array}{l}\text { ck }^{1} \\
\text { Walt }^{2} \\
\text { Sobayeni }\end{array}$ \\
\hline \multicolumn{2}{|c|}{$\begin{array}{l}\text { Affiliations: } \\
{ }^{1} \text { The National School of } \\
\text { Government, Research and } \\
\text { Innovation Unit, South Africa }\end{array}$} \\
\hline \multicolumn{2}{|c|}{$\begin{array}{l}{ }^{2} \text { Department of Business } \\
\text { Management, Central } \\
\text { University of Technology, } \\
\text { South Africa }\end{array}$} \\
\hline \multicolumn{2}{|c|}{$\begin{array}{l}\text { Corresponding author: } \\
\text { Freda van der Walt, } \\
\text { fvdwalt@ @ut.ac.za }\end{array}$} \\
\hline \multicolumn{2}{|c|}{$\begin{array}{l}\text { Dates: } \\
\text { Received: } 03 \text { July } 2016 \\
\text { Accepted: } 28 \text { Oct. } 2016 \\
\text { Published: } 23 \text { Jan. } 2017\end{array}$} \\
\hline \multicolumn{2}{|c|}{$\begin{array}{l}\text { How to cite this article: } \\
\text { Jonck, P., Van der Walt, F., \& } \\
\text { Sobayeni, N.C., 2017, } \\
\text { 'A generational perspective } \\
\text { on work values in a South } \\
\text { African sample', SA Journal } \\
\text { of Industrial Psychology/SA } \\
\text { Tydskrif vir Bedryfsielkunde, } \\
43, \text { a1393. https://doi. } \\
\text { org/10.4102/sajip.v43.1393 }\end{array}$} \\
\hline \multicolumn{2}{|c|}{$\begin{array}{l}\text { Copyright: } \\
\text { ( 2017. The Authors. } \\
\text { Licensee: AOSIS. This work } \\
\text { is licensed under the } \\
\text { Creative Commons } \\
\text { Attribution License. }\end{array}$} \\
\hline \multicolumn{2}{|l|}{ Read online: } \\
\hline 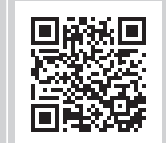 & $\begin{array}{l}\text { Scan this QR } \\
\text { code with your } \\
\text { smart phone or } \\
\text { mobile device } \\
\text { to read online. }\end{array}$ \\
\hline
\end{tabular}

Orientation: In order to ensure harmonious relationships in the workplace, work values of different generational cohorts need to be investigated and understood.

Research purpose: The purpose of this study was to investigate the work values of a South African sample from a generational perspective, in order to foster an understanding of the similarities and differences of different generational cohorts in terms of work values.

Motivation of the study: Understanding the work values of different generational cohorts could assist organisations to manage and retain human capital in an increasingly competitive environment. Furthermore, it could assist organisations to develop an advanced understanding of employee behaviour, which should inform conflict-resolution strategies to deal with reported conflict between different generational cohorts.

Research design, approach and method: The study was conducted within the positivist paradigm and was quantitative in nature. Data were gathered from 301 employees representing three different generational cohorts, namely the Baby Boomers, Generation X and Generation Y. A cross-sectional study was conducted, and data were collected once off by means of the Values Scale. The psychometric properties of the Values Scale have a reliability coefficient of 0.95 , and the scale has been applied successfully in various iterations.

Main findings: The findings indicate statistically significant differences and similarities between the various generational cohorts in terms of work values. More specifically, similarities and differences between the various generational cohorts were observed with regard to the values of authority, creativity, risk and social interaction in the work context.

Practical/managerial implications: Organisations can use the findings of the study to strengthen employee interaction within the work environment. In addition, the findings can be used to inform retention and management strategies, in order to ensure harmonious relationships in the workplace.

Contribution/value-add: The study contributes to the literature on South African generational cohorts and work values.

\section{Introduction}

Considerable interest has been generated globally by researchers regarding the impact of generational differences on employee interaction in the workplace. This is due to the assertion that multicultural environments combined with multigenerational workforces create additional organisational stumbling blocks for global leadership (Roongrerngsuke \& Liefooghe, 2013). As such, it is hypothesised that intergenerational conflict in the workplace occurs as a result of differences in terms of values, cognitions and behaviour, with negative consequences for communication, teamwork and ultimately organisational outcomes (Sessa, Kabacoff, Deal \& Brown, 2007). Furthermore, a new generation of employees is entering the workplace, with different values and preferences towards work, which influences human resource processes (Latkovikj \& Popovska, 2015). Elaborating on the work of D'Amato and Herzfeldt (2008), it is indicated that work motivation and retention concerns are related to generational differences (Seipert \& Baghurst, 2014).

A generation is defined as a distinguishable group that shares a similar birth year and age, and, consequently, noteworthy life events at critical developmental stages (Kupperschmidt, 2000). Life events experienced by various generations have a definite impact on the formation of attitudes and beliefs (Meriac, Woehr \& Banister, 2010). Significant macro-level societal, political and economic events during pre-adolescence result in the formation of a generational identity, which 
remains relatively stable throughout the lifespan of that generation (Fisher \& Crabtree, 2009). Due to ideological and perceptual differences that exist between generational cohorts, conflict and misunderstandings are inevitable (Meriac et al., 2010). In addition, global economic changes and technological advances have given rise to rapid industrialisation, commercialisation, professionalisation and secularisation, to mention just a few of the trends (Steyn \& Kotze, 2004), which have altered individual values, in particular work values and norms (Inglehart \& Baker, 2001).

Work values are pivotal, as they represent what is perceived as important by different individuals, as well as by generational cohorts. They represent changes over time, and they provide justification for opinions and behaviour (Popovska, Latkovic, Jakimovski \& Popovski, 2015). Work values are critical in a multicultural society such as that of South Africa, due to the many systemic changes that have occurred, and which have produced a vast array of human values that are of particular significance in the workplace (Steyn \& Kotze, 2004). The most notable systemic changes that have occurred include Black Economic Empowerment and the advancement of women (Steyn \& Kotze, 2004).

Despite the importance of generational differences with respect to work values, there is a paucity of research on this topic, particularly in the South African context. Globally, in terms of values, it has been found that Generation $Y$ and Generation $X$ value financial stability, community leadership and residing close to family, friends and relatives (Twenge, Campbell \& Freeman, 2012). Furthermore, Generation X and Generation Y reported not to be particularly interested in developing meaningful philosophies on life, finding meaning and purpose, keeping up to date with political affairs and becoming involved in programmes aimed at environmental sustainability, while the older generations valued these intrinsic values highly (Twenge et al., 2012; Van der Walt \& Du Plessis, 2010). The work values literature on the Millennial Generation has been elaborated in the Macedonian context (Latkovikj \& Popovska, 2015). Similarly, a comparative analysis of Greece's Millennial Generation was conducted by comparing the aforementioned with international samples, so as to underscore culture-specific nuances (Papavasileiou \& Lyons, 2014). Generational differences among rural public school principals in North Carolina have also been investigated (Seipert \& Baghurst, 2014). Research has also been conducted into the meaning of work for a sample of nurses (Beukes \& Botha, 2013), however not within the context of a generational perspective.

\section{Research purpose and objectives}

To date, there is a dearth of research studies focusing on the work values of different generations within the South African context. In light of the above, the purpose of this study was to investigate the work values of a South African sample from a generational perspective, in order to foster an understanding of the similarities and differences of different generational cohorts in terms of work values. Specifically, the research objective of the study was to determine the generational differences in terms of work values for a South African sample. The secondary objective was to establish whether generational cohorts differ with regard to the work values that they perceive as important. The research objective was tested by the following hypothesis: 'There is a statistically significant difference between the various generational cohorts in terms of work values in the South African work environment'. The secondary hypothesis of the study is: 'Generational cohorts differ with regard to the work values that they perceive as important'.

\section{Literature review}

\section{Generational cohort theory}

Generational differences can be studied from the perspective of generational cohort theory, which is widely regarded as a theory of social history elaborating on longitudinal fluctuations in generational and public attitudes (Wolf, Carpenter \& Qenani-Petrela, 2005). In his seminal work on generations, Mannheim (1964) indicated that the study of the construct of generations is made possible by five characteristics of society, namely the emergence of new cultural participants, the demise of former participants, limited participation of generational members in history, the transmission of cultural heritage and the continuous nature of generational transitioning (Parry \& Urwin, 2011). Against this background, a generation is defined as the aggregate of individuals born over roughly the same span, or life cycle, who share a common location in history, and hence a common collective character (Drago, 2006).

Generational cohort research is based on the premise that each generation experiences a common distinctive combination of circumstances and environmental forces that are prevalent during their formative years (Bevan-Dye, 2012). Furthermore, this combination of circumstances and environmental forces shapes intrinsic behaviour patterns, distinguishing one generation from another generation. Thus, individuals from the same generation, termed 'generational cohorts', are exposed to the same external environment and events, which may potentially predispose them to having certain overt behaviour and cognitions (Napoli, 2014). However, cognisance is taken of individual differences within these generational cohorts.

Four generational cohorts are identified, namely the Traditionalists (1930-1949), the Baby Boomers (1946-1964), Generation X (1965-1981) and Generation Y, also referred to as the Millennials (1982-2000) (Gursoy, Maier \& Chi, 2008; Twenge, 2010). The Traditionalists grew up during World War II, and most of them travelled extensively in order to find employment (Lancaster \& Stillman, 2010). In the workplace, there are only a few members of this generation present, as most members have retired, and those that are still employed are about to reach retirement age. Most of the Traditionalists were regarded as hard workers during their time, and as a result, sufficient provision for retirement was made (Codrington \& Grant-Marshall, 2006). 
The Baby Boomer generation was exposed to some form of violence and social conflict, because this period had its onset in the wake of World War II (Drago, 2006). In addition, the Baby Boomers were profoundly influenced by the Vietnam War, the civil rights and women's movements, and Watergate, among other things (Sessa et al., 2007). Due to the economic prosperity of the time, the Baby Boomers did not struggle to find employment after completing their schooling (Drago, 2006). In addition, this generation witnessed the foibles of political, religious and business leaders, which led to a lack of respect for and loyalty towards authority and social institutions (Kupperschmidt, 2000). The Baby Boomers seem to be inclined to spend more time at work than at home with their families. In the workplace, they place value on things such as promotions and the size of an office (Shragay \& Tziner, 2011). Within the South African context, the Baby Boomers were exposed to the Sharpeville Massacre in 1960, the rise of the black resistance movement from 1948 to 1960 (e.g. resistance to Bantu Education), the Soweto Uprising of 1976 (which was a protest against the apartheid government enforcing Afrikaans as a medium of instruction in schools) and the banning of the African National Congress and Pan Africanist Congress in 1960, to mention just a few things.

Generation $X$ came of age during the social and economic turmoil that the previous generational cohort left in its wake, and they had to strike out on their own in a challenging economic period (Sessa et al., 2007). This generational cohort has been profoundly influenced by MTV (Music Television), the HIV / AIDS epidemic and an unstable economy characterised by competition (O'Bannon, 2001). Because of the events that this generation has been exposed to, as well as their experience of uncertainty, they became more individualistic and independent than the previous generations (Drago, 2006). Generation X came of age with financial, family and societal insecurity; rapid change; great diversity; and a lack of tradition (Smola \& Sutton, 2002). They grew up with the notion that the only thing that is constant in life is change (Codrington \& Grant-Marshall, 2006), which led to Generation X being flexible and capable of adjusting to changing situations. Because of their inclination to be open to change, Generation $X$ does not find it threatening to work in a multicultural environment, where they will strive towards self-satisfaction and happiness (Shragay \& Tziner, 2011). In South Africa, Generation X is the first generation to be influenced by labour market regulatory codes, such as the Employment Equity Act, Act 55 of 1998, and the Basic Conditions of Employment Act, Act 75 of 1997 (Codrington \& Grant-Marshall, 2006).

Generation Y grew up at a time when everything was technologically connected (Sessa et al., 2007). Various terms have been used to describe this generational cohort, including the terms 'Dot.Com Generation' and 'Net Generation', due to this generation's dependence on technology (Tapscott, 1998), the term 'Generation Why' (due to the inquisitive nature of this generation) and the term 'Generation Next' (Drago, 2006). Generation $Y$ represents approximately $40 \%$ of the South African population (Bevan-Dye, 2012). They prefer to work in teams, and enjoy being challenged (Roux, 2008).
Generation Y also shows a preference for being employed in organisations that are highly technologically orientated (Codrington \& Grant-Marshall, 2006). Apart from showing a preference for being promoted quickly through the ranks in an organisation, members of Generation $Y$ also have a need to experience meaning and fulfilment in the workplace (Twenge \& Campbell, 2008). It is noted that because of the self-confidence that this generation possesses, it is likely that they will become leaders from a very young age (Codrington \& Grant-Marshall, 2006).

\section{Work values}

The concept of values seems to be well researched globally, with various definitions of the concept having been offered over time. The following detailed definition of values is offered: values refer to 'desirable states, objects, goals, or behaviours, transcending specific situations and applied as normative standards to judge and to choose among alternative modes of behaviour' (Schwartz, 1992, p. 2). Work values, specifically, are defined as 'expressions of general values in the work setting' (Ros, Schwartz \& Surkiss, 1999, p. 54). Work values are also defined as 'important factors that influence motivation and positive behaviour at work' (Ueda \& Ohzono, 2013, p. 98). It is noted that work values are an individual's needs, or an 'individual's reinforced preferences', which should be satisfied as a result of participation in the work role (Choi et al., 2013, p. 154). A study of work values is important for organisations, due to the relationship between these values and certain organisational outcomes. Work values and sense of life purpose are postulated to be predictors of commitment and personal involvement that employees experience in the workplace (Ho, 2006). Furthermore, work values play a central role in career development and career choice (Choi et al., 2013). It is also noted that congruence between work value and work type may promote positive individual and organisational outcomes, such as organisational workforce planning and recruitment, individual career decision-making, choice and work adjustment (Wöhrmann, Fasbender \& Deller, 2016).

\section{Previous research findings regarding the generational cohort theory}

Past research studies have focused on work values and possible generational differences (Parry \& Urwin, 2011). Generational differences have been reported between the Baby Boomers and Generation X in terms of career motivation, job commitment, training preferences and collaboration in the workplace (Seipert \& Baghurst, 2014). Sujdak (as cited in Roongrerngsuke \& Liefooghe, 2013) found no statistically significant differences between the Baby Boomers and Generation X with regard to job satisfaction, organisational commitment, job opportunities, organisational communication, job search behaviour and intent to quit. However, the aforementioned researchers highlighted a key shortcoming in the body of knowledge, namely that the majority of generational research has been conducted on middle-class socio-economic strata in developed countries, which raises the question of the generalisability of the findings of this research 
to developing and non-Western countries (Roongrerngsuke \& Liefooghe, 2013, p. 340). Furthermore, the South African society is unique in the sense that it has been socially divided and fragmented, and as such not all social groups have been equally affected by historical events, such as political changes. This shows the need to conduct generational cohort studies in a developing country such as South Africa in order to establish whether citizens of this country have made progress to eradicate the effects of apartheid in terms of individuals mindsets and work values.

\section{Research design Research approach}

The study was conducted in the positivist paradigm and was quantitative in nature. The specific research design that was used in the study was a quantitative cross-sectional design. The rationale for this choice of research design is that it was deemed the most suitable design to test the research hypotheses of the study. Using a cross-sectional design allowed the researchers to collect data from a large number of respondents at a specific point in time, in order to determine whether statistically significant differences exist between the work values of different generational cohorts. A sample was drawn from a population that is representative of the various generational cohorts at a specific point in time (Field \& Buitendach, 2011). As the focus of the study was unambiguously on the generational cohort that respondents belonged to, an ex post facto research design was employed. Thus, respondents belonged to their respective generational cohort prior to data collection (Salkind, 2012, p. 10).

\section{Research method \\ Research participants}

A non-probability convenience sampling method was used to generate the sample, as sampling frames could not be provided by the employers, due to confidentiality concerns. A total of 540 questionnaires were distributed to the initial sample population, and in total, 301 completed questionnaires were returned, which equates to a $55.7 \%$ response rate. Thus, the final sample consisted of 301 respondents. Individuals were the unit of analysis, and the population parameter was working-age individuals who were working or had work experience but were currently unemployed. The population consisted of individuals working at organisations in different sectors, but situated in the same geographical area within South Africa.

The sample consisted of more women $(n=188 ; 62.5 \%)$ than men $(n=112 ; 37.2 \%)$. Most of the respondents belonged to Generation Y $(n=155 ; 51.5 \%)$, followed by Generation $\mathrm{X}(n=112 ; 37.2 \%)$, and lastly the Baby Boomers $(n=34 ; 11.3 \%)$. Only one respondent indicated that they belonged to the Traditionalists category (i.e. respondents 64 years or older). As the sample was drawn in a work setting, the Traditionalists would represent pensioners, or people nearing retirement, and consequently, the one respondent from this category was excluded for purposes of further analysis. With regard to population group, the sample consisted mostly of African respondents $(n=275 ; 91.4 \%)$. This is an acceptable racial distribution, as the sample represented the population composition of South Africa according to mid-year population estimates, which indicate that $80.2 \%$ of the South African population consists of African members (Statistics South Africa, 2015). Most of the respondents ( $n=133 ; 44.2 \%)$ had worked at their place of employ for $0-1$ year, while $37.9 \%$ ( $n=114$ ) had worked for $2-5$ years. Of the participants, $62.8 \%$ ( $n=189)$ had a matriculation certificate as their highest qualification, $2.33 \%(n=7)$ had a national diploma, and 7.6\% $(n=23)$ had honours or bachelor degrees.

\section{Measuring instrument}

The data collection method consisted of the Values Scale (VS) and a biographical data sheet that was developed in order to collect demographic information about the respondents. The biographical data sheet solicited information regarding the participants' gender, generational cohort (i.e. age), the number of years that the participants had worked at their current place of employ, and their highest academic qualification. The VS developed by the Human Sciences Research Council was used as a measure of work values (Langley, 1992). The rationale for the development of the VS was 'to assess the relative importance of the work role as a means of needs satisfaction in the context of other life roles' (Langley, Du Toit \& Herbst, 1992, p. 1). The VS is a four-point Likert-type scale, with response categories ranging from 1 ('of little importance') to 4 ('very important'). The VS measures the following values: ability utilisation, achievement, advancement, aesthetics, altruism, authority, autonomy, creativity, cultural identity, economic rewards, financial security, own lifestyle, personal development, physical activities, physical prowess, prestige, risk, social interaction, social relations, spirituality, variety and pleasant working conditions. Examples of statements included are: 'I find pleasure in the beauty of my work' and 'I make my own decisions at work'. The VS has been used before in the South African context. Both Carvalho (2005) and Langley (1992) reported a Cronbach's alpha of 0.7 for the VS for South African samples. The Cronbach's alpha coefficient for the current study was 0.95 for the total VS. For the specific sub-scales, the reliability ranged between 0.55 and 0.76 which included ability utilisation $(\alpha=0.64)$, achievement $(\alpha=0.66)$, advancement ( $\alpha=0.61)$, aesthetics $(\alpha=0.63)$, altruism $(\alpha=0.75)$, authority ( $\alpha=0.63)$, autonomy $(\alpha=0.62)$, creativity $(\alpha=0.69)$, cultural identity ( $\alpha=0.72)$, economic rewards $(\alpha=0.73)$, economic security $(\alpha=0.69)$, own lifestyle $(\alpha=0.64)$, personal development $(\alpha=0.60)$, physical activities $(\alpha=0.73)$, physical prowess $(\alpha=0.76)$, prestige $(\alpha=0.68)$, risk $(\alpha=0.67)$, social interaction ( $\alpha=0.65)$, social relations $(\alpha=0.66)$, spirituality $(\alpha=0.65)$, variety $(\alpha=0.70)$ and agreeable working conditions $(\alpha=0.55)$.

The VS is classified as a psychological test, and as such, it is regulated by Section 8 of the Employment Equity Act (Act 55 of 1998). The requirements set by this act are that the psychological tests may not be used unless the test has been scientifically shown to be valid and reliable, can be applied fairly to all employees and is not biased against any 
employee or group. In line with the Employment Equity Amendment Act (Act 47 of 2013), which came into effect in January 2014, psychological tests cannot be used if they have not been certified by the Health Professions Council of South Africa. However, the data were collected prior to this amendment coming into force.

\section{Research procedure}

A pilot study was conducted with 10 respondents from the target population. In addition, two psychologists were requested to provide insight into the content of the questionnaire items. After the questionnaires were returned, suggested changes were considered. No changes were suggested to the items included in the VS, but changes were made to the layout of the questionnaire.

Data were collected by means of self-administered questionnaires. This data collection method was deemed effective to collect data on a construct such as work values, because it allows respondents to reflect on questions before answering them, and to answer questions anonymously. The research strategy that was employed involved distribution of the measuring instrument to respondents and collection of the instrument within 14 days of distribution. Although the ideal would have been for the respondents to complete the questionnaire in one setting, it was not possible due to the geographical dispersion of the sample and prior work commitments. After completion, the questionnaires were collected personally from the respondents at a central point. It should be noted that the questionnaires were completed with the explicit purpose of enhancing the current limited body of knowledge regarding work values of generational cohorts in South Africa. Thus, the VS was used for research purposes only as was stated in the consent form. Thus, the data collected were not be utilised for decision-making and/ or psychometric purposes.

\section{Statistical analysis}

Statistical analysis was carried out using SPSS (Statistical Package for the Social Sciences) version 20. Both descriptive and inferential statistical analyses were performed. Descriptive statistics consist of measures of central tendency, including means, medians, standard deviations, skewness and kurtosis (Salkind, 2012). Inferential statistical analysis was performed using the Kruskal-Wallis test, to determine statistically significant differences between the various generational cohorts with regard to the construct of work values, as the KolmogorovSmirnov test for normality indicated that the distribution was skewed. A Cronbach's alpha coefficient was calculated to determine the reliability of the measuring instrument.

\section{Results}

The objective of the research was to determine generational differences in terms of work values. To this end, the generational data were firstly subjected to analysis using measures of central tendency. The results of the analysis are presented in Table 1 and subsequent tables. In each case, the median represents the $50 \%$ mark. The median and the mean are compared with each other to determine whether the evaluation is positive or negative. The measures of central tendency, including the mean, the median, the standard deviation and the maximum and minimum scores, for each generational cohort are reported.

As is evident from Table 1, only 6 of the 22 work values measured had means exceeding 50\%, namely authority, creativity, cultural identity, economic security, risk and social relationships. This indicates that only 6 of the 22 work values measured were important to Generation Y.

The scores for the different levels of the variable of work values for Generation $X$ are depicted in Table 2. The results

TABLE 1: Measures of central tendency for Generation $Y$ with regard to work values.

\begin{tabular}{|c|c|c|c|c|c|c|c|}
\hline Variable & Level of the variable & Minimum & Maximum & Median & Mean & Standard deviation & $50 \%$ \\
\hline \multirow[t]{21}{*}{ Work values } & Ability utilisation & 1 & 4 & 3.60 & 3.58 & 0.446 & 3.60 \\
\hline & Achievement & 1 & 4 & 3.60 & 3.51 & 0.455 & 3.60 \\
\hline & Advancement & 1 & 4 & 3.60 & 3.51 & 0.450 & 3.60 \\
\hline & Aesthetics & 2 & 4 & 3.20 & 3.13 & 0.525 & 3.20 \\
\hline & Altruism & 1 & 4 & 3.40 & 3.26 & 0.561 & 3.40 \\
\hline & Authority & 1 & 4 & 2.80 & 2.81 & 0.509 & 2.80 \\
\hline & Autonomy & 1 & 4 & 3.00 & 2.87 & 0.597 & 3.00 \\
\hline & Creativity & 1 & 4 & 3.20 & 3.23 & 0.496 & 3.20 \\
\hline & Cultural identity & 1 & 4 & 3.00 & 3.01 & 0.625 & 3.00 \\
\hline & Economic rewards & 1 & 4 & 3.40 & 3.39 & 0.590 & 3.40 \\
\hline & Economic security & 2 & 4 & 3.40 & 3.40 & 0.508 & 3.40 \\
\hline & Own lifestyle & 2 & 4 & 3.20 & 3.09 & 0.544 & 3.20 \\
\hline & Personal development & 1 & 4 & 3.60 & 3.48 & 0.423 & 3.60 \\
\hline & Physical activities & 1 & 4 & 3.00 & 2.97 & 0.619 & 3.00 \\
\hline & Prestige & 1 & 4 & 3.40 & 3.29 & 0.561 & 3.40 \\
\hline & Risk & 1 & 4 & 2.40 & 2.49 & 0.628 & 2.40 \\
\hline & Social interaction & 1 & 4 & 3.00 & 2.87 & 0.553 & 3.00 \\
\hline & Social relationships & 1 & 4 & 2.60 & 2.68 & 0.607 & 2.60 \\
\hline & Spirituality & 2 & 4 & 3.20 & 3.14 & 0.523 & 3.20 \\
\hline & Variety & 1 & 4 & 3.00 & 2.94 & 0.569 & 3.00 \\
\hline & Working conditions & 1 & 4 & 3.20 & 3.10 & 0.497 & 3.20 \\
\hline
\end{tabular}


TABLE 2: Measures of central tendency for Generation $X$ with regard to work values.

\begin{tabular}{|c|c|c|c|c|c|c|c|}
\hline Variable & Level of the variable & Minimum & Maximum & Median & Mean & Standard deviation & $50 \%$ \\
\hline \multirow[t]{21}{*}{ Work values } & Ability utilisation & 2 & 4 & 3.60 & 3.54 & 0.428 & 3.60 \\
\hline & Achievement & 2 & 4 & 3.60 & 3.51 & 0.417 & 3.60 \\
\hline & Advancement & 2 & 4 & 3.60 & 3.53 & 0.408 & 3.60 \\
\hline & Aesthetics & 2 & 4 & 3.40 & 3.30 & 0.498 & 3.40 \\
\hline & Altruism & 2 & 4 & 3.60 & 3.43 & 0.485 & 3.60 \\
\hline & Authority & 1 & 4 & 3.00 & 2.95 & 0.578 & 3.00 \\
\hline & Autonomy & 2 & 4 & 3.00 & 2.99 & 0.556 & 3.00 \\
\hline & Creativity & 2 & 4 & 3.40 & 3.32 & 0.493 & 3.40 \\
\hline & Cultural identity & 2 & 4 & 3.20 & 3.05 & 0.616 & 3.20 \\
\hline & Economic rewards & 2 & 4 & 3.60 & 3.46 & 0.495 & 3.60 \\
\hline & Economic security & 2 & 4 & 3.60 & 3.45 & 0.443 & 3.60 \\
\hline & Own lifestyle & 2 & 4 & 3.20 & 3.14 & 0.570 & 3.20 \\
\hline & Personal development & 2 & 4 & 3.60 & 3.57 & 0.403 & 3.60 \\
\hline & Physical activities & 1 & 4 & 3.00 & 3.05 & 0.596 & 3.00 \\
\hline & Prestige & 2 & 4 & 3.33 & 3.26 & 0.528 & 3.33 \\
\hline & Risk & 1 & 4 & 2.60 & 2.50 & 0.646 & 2.60 \\
\hline & Social interaction & 2 & 4 & 3.00 & 3.08 & 0.541 & 3.00 \\
\hline & Social relationships & 1 & 4 & 2.80 & 2.71 & 0.629 & 2.80 \\
\hline & Spirituality & 2 & 4 & 3.23 & 3.25 & 0.509 & 3.23 \\
\hline & Variety & 1 & 4 & 3.20 & 3.09 & 0.538 & 3.20 \\
\hline & Working conditions & 1 & 4 & 3.20 & 3.16 & 0.545 & 3.20 \\
\hline
\end{tabular}

illustrate that only 3 of the 22 work values measured had an average score of more than $50 \%$ for Generation X, namely physical activity, social interaction and spirituality.

The scores for the different levels of the variable of work values for the Baby Boomer cohort are presented in Table 3.

Table 3 shows that the Baby Boomer cohort perceived 11 of the 22 measured work values as important to them, as indicated by an average score of more than $50 \%$. The work values that were measured as being important to the Baby Boomers were aesthetics, altruism, authority, creativity, economic rewards, physical prowess, prestige, risk, social interaction, social relationships and agreeable working conditions.

From the aforementioned results, it would appear that the generational cohorts differ with regard to the work values that they perceive as important. Both Generation $Y$ and Generation $X$ regard work values as less important in comparison with the Baby Boomers. To test the hypothesis 'There is a statistically significant difference between the various generational cohorts in terms of work values in the South African work environment', a Kruskal-Wallis test was performed. The results of the test are depicted in Table 4 .

According to the results presented in Table 4, statistically significant differences between the various generational cohorts in terms of work values were found. On the 99th percentile, statistically significant differences were observed between the different generations with regard to aesthetics, risk and social interaction. On the 95th percentile, statistically significant differences were found for altruism, creativity, cultural identity, personal development, prestige and variety. The greatest difference between the generations was observed in the work value of social interaction.
With regard to aesthetics, Generation $X$ had the highest ranking (mean rank $=169.58)$, followed by Generation $\mathrm{Y}$ (mean rank = 142.78), and then the Baby Boomers (mean rank $=127.26)$. Thus, for Generation $X$, aesthetics as work value was more important in comparison with the other generational cohorts. With regard to altruism, Generation $X$ had the highest ranking once again (mean rank $=169.39$ ), followed by Generation Y (mean rank = 141.72), and then the Baby Boomers (mean rank = 132.74). It would appear that altruism was also more important to Generation $X$ in comparison with Generation $\mathrm{Y}$ and the Baby Boomer cohort. Similar results were shown for creativity, where Generation $X$ once again had the highest ranking (mean rank $=164.05)$, followed by Generation Y (mean rank = 147.64), and then the Baby Boomers (mean rank $=123.32$ ). With regard to cultural identity, Generations X and Y were almost evenly distributed, with a mean rank of 159.76, followed by 153.55 for Generation Y. The Baby Boomers had the lowest mean rank (mean rank $=110.53)$.

In terms of the results for personal development, a sizable difference was observed between the mean rank of Generation X and that of the Baby Boomer cohort. The mean rank of Generation X was 165.29, while that of the Baby Boomers was 118.44. Generation Y had a mean rank of 147.82. In terms of prestige, Generations $X$ (mean rank $=159.34)$ and $Y($ mean rank $=151.22)$ were almost evenly distributed, while the Baby Boomers had the lowest mean rank, at 112.25. With regard to risk, there was a difference of only 0.75 between Generation X (mean score $=156.90)$ and Generation Y (mean score $=156.15)$. By contrast, the Baby Boomers had a mean score of 108.12, which was significantly lower than the mean scores of the other generational cohorts. A different pattern was noticed for social interaction. Generation $X$ had the highest mean score (mean rank $=172.89$ ), while Generation 
TABLE 3: Measures of central tendency for the Baby Boomer cohort with regard to work values.

\begin{tabular}{|c|c|c|c|c|c|c|c|}
\hline Variable & Level of the variable & Minimum & Maximum & Median & Mean & Standard deviation & $50 \%$ \\
\hline \multirow[t]{20}{*}{ Work values } & Ability utilisation & 3 & 4 & 3.60 & 3.55 & 0.341 & 3.60 \\
\hline & Achievement & 3 & 4 & 3.55 & 3.48 & 0.347 & 3.55 \\
\hline & Advancement & 2 & 4 & 3.40 & 3.39 & 0.407 & 3.40 \\
\hline & Aesthetics & 2 & 4 & 3.00 & 3.01 & 0.617 & 3.00 \\
\hline & Altruism & 2 & 4 & 3.20 & 3.23 & 0.465 & 3.20 \\
\hline & Authority & 1 & 4 & 2.80 & 2.85 & 0.632 & 2.80 \\
\hline & Creativity & 2 & 4 & 3.00 & 3.10 & 0.457 & 3.00 \\
\hline & Cultural identity & 1 & 4 & 2.70 & 2.61 & 0.810 & 2.70 \\
\hline & Economic rewards & 2 & 4 & 3.23 & 3.26 & 0.540 & 3.23 \\
\hline & Economic security & 3 & 4 & 3.40 & 3.38 & 0.383 & 3.40 \\
\hline & Own lifestyle & 2 & 4 & 3.00 & 2.94 & 0.562 & 3.00 \\
\hline & Personal development & 3 & 4 & 3.40 & 3.37 & 0.381 & 3.40 \\
\hline & Physical activities & 2 & 4 & 3.20 & 2.98 & 0.598 & 3.20 \\
\hline & Prestige & 2 & 4 & 3.00 & 3.01 & 0.557 & 3.00 \\
\hline & Risk & 1 & 4 & 2.00 & 2.08 & 0.768 & 2.00 \\
\hline & Social interaction & 2 & 4 & 2.80 & 2.86 & 0.559 & 2.80 \\
\hline & Social relationships & 1 & 4 & 2.40 & 2.47 & 0.618 & 2.40 \\
\hline & Spirituality & 2 & 4 & 3.20 & 3.16 & 0.578 & 3.20 \\
\hline & Variety & 1 & 4 & 2.80 & 2.77 & 0.655 & 2.80 \\
\hline & Working conditions & 2 & 4 & 2.90 & 3.02 & 0.555 & 2.90 \\
\hline
\end{tabular}

TABLE 4: Kruskal-Wallis test results for work values as dependent variable and generational cohort as independent variable.

\begin{tabular}{llccc}
\hline Variable & Level of the variable & Chi-square & $d f$ & $p$ \\
\hline Work values & Ability utilisation & 1.314 & 2 & 0.518 \\
& Achievement & 0.769 & 2 & 0.681 \\
Advancement & 3.848 & 2 & 0.146 \\
Aesthetics & 9.138 & 2 & $0.010^{* *}$ \\
Altruism & 8.378 & 2 & $0.015^{*}$ \\
Authority & 4.919 & 2 & 0.085 \\
Autonomy & 3.209 & 2 & 0.201 \\
Creativity & 6.283 & 2 & $0.043^{*}$ \\
Cultural identity & 8.697 & 2 & $0.013^{*}$ \\
Economic rewards & 3.669 & 2 & 0.160 \\
Economic security & 1.365 & 2 & 0.505 \\
Own lifestyle & 4.042 & 2 & 0.133 \\
Personal development & 8.192 & 2 & $0.017^{*}$ \\
Physical activities & 0.666 & 2 & 0.717 \\
Physical prowess & 1.195 & 2 & 0.550 \\
Prestige & 8.270 & 2 & $0.016^{*}$ \\
Risk & 9.379 & 2 & $0.009^{* *}$ \\
Social interaction & 11.426 & 2 & $0.003^{* *}$ \\
Social relationships & 3.519 & 2 & 0.173 \\
Spirituality & 3.164 & 2 & 0.206 \\
Variety & 8.192 & 2 & $0.017^{*}$ \\
Working conditions & 2.726 & 2 & 0.256 \\
\hline
\end{tabular}

$*, p \leq 0.05 ; * *, p \leq 0.01$.

$\mathrm{Y}($ mean rank $=138.39)$ and the Baby Boomer cohort (mean rank $=136.40)$ were almost even. With regard to variety, Generation $X$ once again had the highest ranking (mean rank $=159.64)$, followed by Generation $Y$ (mean rank = 148.74), and then the Baby Boomers (mean rank $=132.87$ ).

The results presented in Table 1 indicate that 6 of the 22 work values measured were important to Generation Y, namely authority, creativity, cultural identity, risk, economic security and social relationships. The work values emphasised by Generation X respondents were somewhat different from
TABLE 5: Work values profiles of the different generational cohorts.

\begin{tabular}{lcl}
\hline Cohort & Born between & Work values \\
\hline Generation Y & $1990-2000$ & $\begin{array}{l}\text { Authority, creativity, cultural identity, risk, } \\
\text { social relationships, economic security }\end{array}$ \\
Generation X & $1970-1989$ & $\begin{array}{l}\text { Physical activities, social interaction, } \\
\text { spirituality }\end{array}$ \\
The Baby Boomers & $1950-1969$ & $\begin{array}{l}\text { Aesthetics, authority, creativity, economic } \\
\text { rewards, economic security, physical } \\
\text { prowess, prestige, risk, social interaction, } \\
\text { social relationships, agreeable working } \\
\text { conditions }\end{array}$ \\
\hline
\end{tabular}

those of Generation Y respondents, as is indicated above. The results presented in Table 2 indicate that only three work values were important to respondents belonging to Generation X, namely physical activities, social interaction and spirituality. Table 3 indicates that 11 of the 22 work values measured were important to respondents belonging to the Baby Boomer generational cohort, namely aesthetics, altruism, authority, creativity, economic rewards, physical prowess, prestige, risk, social interaction, social relationships and working conditions. Table 5 below provides a summary of the work values of each generational cohort.

\section{Discussion}

\section{Outline of the results}

From the above results, similarities and differences between generational cohorts in terms of work values were found. More similarities were established between the Baby Boomers and Generation $\mathrm{Y}$ than between the Baby Boomers and Generation X, or between Generation Y and Generation X. The above results show that both the Baby Boomer respondents and the Generation $\mathrm{Y}$ respondents value authority, creativity, risk and social relationships in the work context. These findings contradict those reported by Robbins, Judge, Odendaal and Roodt (2009) and Jurkiewicz (2000), who found that the Baby Boomers and Generation $X$ are 
more alike than different. However, Ching and Kee (2012) assert that generational studies have up to now mainly been conducted in a Western setting. The findings of their study, which included a Malaysian sample, differ considerably from the findings of previous studies conducted in Western countries. However, Ching and Kee's (2012, p. 243) findings are consistent with the findings of this study. The most interesting differences reported were, firstly, that both Generation $\mathrm{Y}$ and the Baby Boomers valued authority. This is a particularly interesting finding, since Generation $\mathrm{Y}$ has been described as less inclined to accept authority and formal leadership (Roux, 2008). Secondly, both Generation Y and Baby Boomers seemed to value relationships through which they can make a contribution to society. In addition, Generation X sought to connect with others, but their connection was more spiritually based. Another surprising finding was that only Generation Y valued cultural identity.

\section{Practical implications}

In terms of the work values of different generations working within the South African work environment, it was not expected to find that there are more similarities between Generation $Y$ and the Baby Boomers than between Generation $Y$ and Generation $X$, although there were also not many similarities that were found between the Baby Boomers and Generation X. This finding could hold both positive and negative implications for organisations. When employees have similar work values, it may be easier for management to structure work in such a way that will satisfy all of their employees. Among other things, having similar work values across generations could enable mutual understanding and cooperation in the organisation, where employees will work together towards a common vision. However, the generational cohorts included in this study also showed differences in work values. This could hold negative implications for the organisation. When employees have dissimilar work values, the organisation leaders will need to ensure that diverse needs of the workforce are met, based on the preferences of each cohort. If these needs are not met, high labour turnover, job dissatisfaction, a high number of conflicts and disloyalty to the organisation could be some of the implications that such an organisation will face.

\section{Limitations and recommendations}

The following limitations should be taken into consideration when interpreting the findings of this study. Firstly, data gathering took place in a specific location, and a nonprobability sampling technique was used to generate the sample. As a result, the external validity of the research reported on might be compromised. Even though trends can be identified, caution is advised when generalising the findings to a larger population. Because the research was only conducted in one geographical region, it is recommended that the study be replicated nationally. Secondly, although the sample was representative of the South African population, it consisted mainly of African respondents. As a result, the findings are subject to cultural bias.
Despite the aforementioned limitations, the study provides some valuable insights. It should be noted that the VS used to measure work values does not necessarily represent the work values of the South African workforce and further investigation into the relevance of the measuring instrument is suggested for future research.

Aligning the needs of an organisation with those of the employees is critical in order to create a healthy and productive work environment. The Baby Boomers and Generation Y share the work value of social relationships, while both the Baby Boomers and Generation X attach much importance to social interaction. It is thus recommended that organisations focus more on team work and collaboration, as the findings of the study indicate that all the generations investigated would be good team players, and teams would advance the effectiveness and competitive advantage of organisations. It is further recommended that managerial styles within organisations should not be autocratic, but participative, so as to ensure that employee contributions and creativity are valued. A stronger focus should also be placed on human capital development, which will create opportunities for personal development and growth. Furthermore, employees should be allowed to use office space creatively, in order to make the working environment more appealing and comfortable. This will not only strengthen employee interaction within the work environment, but it will also ensure harmonious relations between different generational cohorts in the workplace, and, as such, human capital will be retained.

\section{Conclusion}

This study and its findings offered valuable insight into generational differences in terms of work values within the South African work environment. It is evident that generational differences exist in terms of work values. However, it should also be acknowledged that there are certain similarities between generational cohorts with regard to work values. Organisations should capitalise on and build on these similarities, particularly in the light of prevailing cultural differences.

\section{Acknowledgements}

We thank Anthony Sparg for editing this article.

\section{Competing interests}

The authors declare that they do not have any competing interests that may have inappropriately influenced them in writing this article.

\section{Authors' contributions}

P.J. was the project leader and contributed towards the literature review and data interpretation. F.v.d.W. contributed towards the literature review and data interpretation, and N.S. contributed towards the literature review, data collection and data interpretation. 


\section{References}

Beukes, I., \& Botha, E. (2013). Organisational commitment, work engagement and meaning of work of nursing staff in hospitals. South African Journal of Industria Psychology, 39(2), 1-10. http://dx.doi.org/10.4102/sajip.v39i2.1144

Bevan-Dye, A.L. (2012). Relationship between self-esteem and Facebook usage amongst black Generation Y students. African Journal for Physical, Health Education, Recreation and Dance, Supplement, 1(1), 33-49.

Carvalho, A. (2005). Meaning of work and life role salience in a South African context A cross-cultural comparison. Unpublished master's dissertation, University of Johannesburg, Johannesburg.

Ching, S., \& Kee, D. (2012). Work values-career commitment relationship of Generation-Y teachers in Malaysia. Proceedings of the International Conference on Economics Marketing and Management (pp. 242-246). Singapore: IACSIT on Econo
Press.

Choi, B.Y., Kim, B., Jang, S.H., Jung, S.H., Ahn, S.S., Lee, S.M., et al. (2013). An individual's work values in career development. Journal of Employment Counseling, 50(4), 154-165. https://doi.org/10.1002/j.2161-1920.2013.00034.x

Codrington, G., \& Grant-Marshall, S. (2006). Mind the gap. Cape Town: Penguin Books.

D'Amato, A., \& Herzfeldt, R. (2008). Learning orientation, organizational commitment and talent retention across generations: A study of European managers.
Journal of Managerial Psychology, 23(8), 929-953. https://doi.org/10.1108/ 02683940810904402

Drago, J. (2006). Generational theory: Implications for recruiting the Millennials USAWC Strategy Research Project. Pennsylvania: Army War College.

Field, L.K., \& Buitendach, J.H. (2011). Happiness, work engagement and organisational commitment of support staff at a tertiary education institution in South Africa. South African Journal of Industrial Psychology, 37(1), 1-10. http://dx.doi.org/ 10.4102/sajip.v37i1.946

Fisher, T.F., \& Crabtree, J.L. (2009). Generational cohort theory: Have we overlooked an important aspect of the entry-level occupational therapy doctorate debate? The American Journal of Occupational Therapy, 63(5), 656-660. https://doi. org/10.5014/ajot.63.5.656

Gursoy, D., Maier, T.A., \& Chi, C.G. (2008). Generational differences: An examination of work values and generational gaps in the hospitality workforce. Internationa Journal of Hospitality Management, 27(3), 448-458. https://doi.org/10.1016/j. ijhm.2007.11.002

Ho, C.-C. (2006). A study of the relationships between work values, job involvement and organisational commitment among Taiwanese nurses. Unpublished doctoral thesis, Queensland University of Technology, Australia.

Inglehart, R. \& Baker, W. (2001). Modernization's challenge to traditional values: Who's afraid of Ronald MacDonald? The Futurist, 35(2), 16.

Jurkiewicz, C.L. (2000). Generation X and the public employee. Public Personnel Management, 29(1), 55-74. https://doi.org/10.1177/009102600002900105

Kupperschmidt, B. (2000). Multigeneration employees: Strategies for effective management. The Health Care Manager, 19(1), 65-76. https://doi.org/10.1097/ 00126450-200019010-00011

Lancaster, L.C., \& Stillman, D. (2010). The M-factor: How the Millennial generation is rocking the workplace. New York: HarperCollins.

Langley, R. (1992). Manual: The Values Scale. Pretoria: Human Sciences Research Council.

Langley, R., Du Toit, R., \& Herbst, D. (1992). Manual for the Values Scale. Pretoria: Human Sciences Research Council.

Latkovikj, M.T., \& Popovska, M.B. (2015). Work values and preferences of the new workforce: HRM implications for Macedonian Millennial Generation. Journal of Advanced Management Science, 4(4), 312-319.

Mannheim, K. 1964. Über das Wesen und die Bedeuteng des wirtschaftlichen Erfolgsstrebens. Ein Betrag zur Wirtschaftssoziologie (zuerst 1930). In K.H. Wolf (Ed.), Wissenssoziologie. Auswahl aus dem Werk (pp. 625-687). Berlin/Neuwied: (Ed.), Wissenssoz

Meriac, J.P., Woehr, D.J., \& Banister, C. (2010). Generational differences in work ethic: An examination of measurement equivalence across three cohorts. Journal of Business and Psychology, 25(2), 315-324. https://doi.org/10.1007/s10869-0109164-7

Napoli, A. (2014). Social media use and generational identity: Issues and consequences on peer-to-peer and cross-generational relationships - An empirical study. Participations: Journal of Audience \& Reception Studies, 11(2), 182-206.

O'Bannon, G. (2001). Managing our future: The Generation X factor. Public Personnel Management, 30(1), 95-109. https://doi.org/10.1177/009102600103000109
Papavasileiou, E.F., \& Lyons, S.T. (2014). A comparative analysis of the work values of Greece's 'Millennial' generation. The International Journal of Human Resource Management. http://dx.doi.org/10.1080/09585192.2014.985325

Parry, E., \& Urwin, P. (2011). Generational differences in work values: A review of theory and evidence. International Journal of Management Reviews, 13(1), 79-96. https://doi.org/10.1111/j.1468-2370.2010.00285.x

Popovska, M.B., Latkovic, M.T., Jakimovski, J., \& Popovski, V. (2015). Work values of the Macedonian workforce. Journal of Advanced Management Science, 3(2), 158-161. https://doi.org/10.12720/joams.3.2.158-161

Robbins, S.P., Judge, T.A., Odendaal, A., \& Roodt, G. (2009). Organisational behaviour Global and Southern African perspectives. (2nd ed.). Cape Town: Pearson Education South Africa.

Roongrerngsuke, S., \& Liefooghe, A. (2013). Attracting gold-collar workers: Comparing organizational attractiveness and work-related values across generations in China, India and Thailand. Asia Pacific Business Review, 19(3), 337-355. https://doi.org/ 10.1080/13602381.2012.747784

Ros, M., Schwartz, S.H., \& Surkiss, S. (1999). Basic individual values, work values, and the meaning of work. Applied Psychology: An International Review, 48(1), 49-71. https://doi.org/10.1111/j.1464-0597.1999.tb00048.x

Roux, D.F. (2008). Approaches, expectations and perceptions of different generations regarding culture and leadership in the Engineering Department at Sishen Mine. regarding culture and leadership in the Engineering Department at
Unpublished MBA thesis, University of Stellenbosch, Stellenbosch.

Salkind, N. (2012). Exploring research. (8th ed.). New York: Pearson.

Schwartz, S.H. (1992). Universals in the content and structure of values: Theoretical advances and empirical tests in 20 countries. Advances in Experimental Socia Psychology, 25, 1-65. https://doi.org/10.1016/S0065-2601(08)60281-6

Seipert, K., \& Baghurst, T. (2014). Contrasting work values of Baby Boomers and Generation X rural public school principals. Public Administration Quarterly, 38(3), 347-370.

Sessa, V.I., Kabacoff, R.I., Deal, J., \& Brown, H. (2007). Generational differences in leader values and leadership behaviors. The Psychologist-Manager Journal, 10(1) leader values and leadership behaviors. The Psycholog
47-74. https://doi.org/10.1080/10887150709336612

Shragay, D., \& Tziner, A. (2011). The generational effect on the relationship between job involvement, work satisfaction, and organizational citizenship behavior. Journal of Work and Organizational Psychology, 27(2), 143-157.

Smola, K.W., \& Sutton, C.D. (2002). Generational differences: Revisiting generational work values for the new millennium. Journal of Organizational Behavior, 23(4), 363-382. https://doi.org/10.1002/job.147

Statistics South Africa. (2015). Mid-year population estimates. Pretoria: Statistical Release P0302.

Steyn, C. \& Kotze, H. 2004. Work value change in South Africa between 1995 and 2001: Race, gender and occupations compared. South African Journal of Labour Relations, Autumn, 4-33.

Sujdak, E.J. (2003). An investigation of the correlation of job satisfaction, organizational commitment, perceived job opportunity, organizational communications, job search behavior, and the intent to turnover in IT professionals. Dissertation Abstracts International, Section A. Humanities and Social Sciences, 63(8), 2940.

Tapscott, D. (1998). Growing up digital: The rise of the net generation. New York: McGraw-Hill.

Twenge, J.M. (2010). A review of the empirical evidence on generational differences in work attitudes. Journal of Business Psychology, 25, 201-210. https://doi.org/ 10.1007/s10869-010-9165-6

Twenge, J.M., \& Campbell, S.M. (2008). Generational differences in psychological traits and their impact on the workplace. Journal of Managerial Psychology, 23(8), 862-877. https://doi.org/10.1108/02683940810904367

Twenge, J.M., Campbell, W.K., \& Freeman, E.C. (2012). Generational differences in young adults' life goals, concern for others, and civic orientation, 1966-2009. Journal of Personality and Social Psychology, 102(5), 1045-1062. https://doi. org/10.1037/a0027408

Ueda, Y., \& Ohzono, Y. (2013). Differences in work values by gender, marital status, and generation: An analysis of data collected from 'Working Persons Survey, 2010'. International Journal of Human Resource Studies, 3(2), 28-41. https://doi.org/ 10.5296/ijhrs.v3i2.3131

Van der Walt, S., \& Du Plessis, T. (2010). Leveraging multi-generational workforce values in interactive information societies. South African Journal of Information Management, 12(1), 1-7. https://doi.org/10.4102/sajim.v12i1.441

Wöhrmann, A.M., Fasbender, U., \& Deller, J. (2016). Using work values to predict postretirement work intentions. The Career Development Quarterly, 64(2), 98-113. https://doi.org/10.1002/cdq.12044

Wolf, M.M., Carpenter, S., \& Qenani-Petrela, E. (2005). A comparison of X, Y, and Boomer generation wine consumers in California. Journal of Food Distribution Research, 36(1), 186-191. 